\title{
The Role of Cultural Values in Understanding the Challenges faced by Female Entrepreneurs in Nigeria
}

\begin{abstract}
Purpose: This paper examines the challenges female entrepreneurs face in the development of their business in the context of Nigeria. In so doing, it addresses a gap in the literature on the experiences of female entrepreneurs in a non-Western context and acknowledges the contribution that women make in this area of work.
\end{abstract}

Design: It draws on survey data from 274 female entrepreneurs currently engaged in their businesses in three states-Lagos (Nigeria's largest city), Ogun, and Oyo within the south west of Nigeria.

Findings: Results indicate that female entrepreneurs are generally confident and resourceful and that they enjoy the challenge of entrepreneurial activity. As in the West, they experience difficulties relating to family commitments and access to finance - as well as problems gaining acceptance and accessing networks.

Originality: It is argued that cultural values specific to the situation mean that these challenges, while common to female entrepreneurs in other national contexts, 'play out' differentially and that they are experienced with different levels of depth and 'intensity'. It is also argued that future research might uncover at a deeper level and drawing on qualitative methodology how some of the factors identified are experienced in women's day to day lives. The paper suggests some policy implications in the form of support for female entrepreneurs in this context.

Key words: female entrepreneurs, challenges, Nigeria 
Dr. Chima Mordi

Brunel Business School

Brunel University

Uxbridge

UB8 3PH

Chima.mordi@brunel.ac.uk

Prof. Ruth Simpson

Brunel Business School

Brunel University

Uxbridge

UB8 3PH

R.simpson@brunel.ac.uk

Dr. Satwinder Singh

Brunel Business School

Brunel University

Uxbridge

London

UB8 3PH

Email: Satwinder.singh@brunel.ac.uk

Dr. Chinonye Okafor

College of Business and Social sciences

Covenant University

emmanueloutreach@yahoo.com 


\section{INTRODUCTION}

Over the last three decades there has been a growing literature on the shift away from planned and managed economies and the hegemony wielded by large transnational firms towards an entrepreneurial economy where small to medium firms or entrepreneurs play greater economic roles (Verheul \& Thurik, 2000). The entrepreneurship literature has increasingly acknowledged the desire by women to be economically independent and their role and contribution as female entrepreneurs in shaping the labour market (Goffee \& Scase, 1985). This growing affirmation of the significance of female entrepreneurship has covered a variety of themes which include but are not limited to studies examining the management practices of successful female entrepreneurs (Carter \& Cannon, 1991), characteristics of female entrepreneurs (Sexton \& Bowman-Upton, 1990), start-up capital differences between male and female entrepreneurs and the challenges they face (Verheul \& Thurik, 2000; Marlow and Patton, 2005). Others have reviewed the way the entrepreneurship observers have sought to research and expand the subject. Here, De Bruin et al. (2007) and Blackburn and Kovalainen (2009) have called for an integrated framework of analysis which reflects women entrepreneurship in the macro, meso and micro environments. As they argue, these studies should include cultural contextual disparities so differences can easily be drawn across countries and institutions.

Following from the above, while extant entrepreneurial literature has undoubtedly increased our understanding of entrepreneurs and the gender dynamics of entrepreneurship, a key concern is the tendency for mainstream studies to focus on entrepreneurship issues in Western developed economies to the neglect of developing 
economies. The resultant effect is that we know comparatively little about the nature of the challenges that female entrepreneurs encounter in developing countries such as Nigeria. In this respect, there has been a growing call by scholars (e.g. Gartner, 1995; Kitching \& Woldie, 2004; Carter, 2000) for country-specific studies in non-Western contexts in order to provide insight and deepen our knowledge of the socially constructed nature of female entrepreneurs. For instance, Gartner (1995:70) argues that researchers have had a tendency to 'underestimate the influence of external factors and overestimate the influence of internal or personal factors when making judgements about the behaviour of other individuals'. He has called for studies that emphasise the effects of institutional or societal aspects.

This study seeks to address this research gap by exploring the challenges that female entrepreneurs face in the specific context of Nigeria. As a developing country where women are often under-utilized, self-employment is sought as a means to alleviate poverty, unemployment and gender based occupational segregation (Alarape, 2009). Female entrepreneurs are both an important part of the Nigerian economy and largely hidden within the informal sector (Aderemi et al, 2008), in a context where formal avenues of employment are often reserved for men. Given that on a general level, entrepreneurial activity is strongly associated with increased GDP and hence welfare (McClelland et al, 2005), this suggests a need to understand the nature of female entrepreneurship in a country where women are impeded by a variety of barriers that stem from the interaction of socio-cultural values and strong family orientations which, as Ituma and Simpson (2007) argue, influence the choices they make. In this respect, there is no doubt that women are contributing significantly to entrepreneurial development. For example, it is estimated that 
globally women account for 25 percent to 33 percent of all businesses (National Foundation for Business Owners, 1998:2). While in the US and the UK they account for $33 \%$ and $26 \%$ of business start-ups respectively (Carter, 2000), in Sub-Saharan Africa the figure is higher at 80 percent (Kitching \& Woldie, 2004). However, despite this contribution, for a long time women were not considered as entrepreneurs. Although there are significant changes in the perception of the female entrepreneur, many women in Sub-Saharan African countries are still marginalised as a result of their gender (Kuada, 2009).

From the above it appears imperative to explore the challenges that female entrepreneurs in Nigeria face in order to facilitate their development. In addressing this question, the paper has the following structure. In the next section, we highlight the gender and entrepreneurship career issues in general and then analyse the impediments to women entrepreneurial development with particular reference to Nigeria. The next section explains the propositions, sample and methodology. We then present and discuss the findings and argue that while many challenges identified are common to West, they are experienced differentially and are strongly influenced by the nature of the cultural values in context.

\section{GENDER AND THE ENTREPRENEURIAL CAREER CHOICE}

Definitions of the term entrepreneur tend to assume and emphasise a particular view of the nature and purpose of entrepreneurial activities. An entrepreneur is defined as one who undertakes a commercial enterprise and who is an organisational creator and innovator (Gartner, 1990; 2004); one who prospects for or exploits opportunities and who has a tenacity to face challenges (Winn, 2005). Other conceptual constituents include smallness, competition, deregulation, innovation and risk (Verheul \& Thurik, 2000) - traits and 
behaviour that have been identified by some authors as gendered masculine (e.g.Lewis, 2006; Bird and Brush, 2002; Marlow and Patton, 2005) and which accordingly contribute to entrepreneurship being seen as a typically male career path.

The literature points to a variety of intrinsic and extrinsic factors that might influence women to choose an entrepreneurial career. Intrinsic factors include the person's personality or traits such as having a proactive, assertive personality, being self-governed and positive (Akrivos et al., 2007). In this respect, female entrepreneurs have been found to be less oriented to financial reward than men (Rosa et al, 1996), valuing work satisfaction and challenge, and to hold 'androgynous' or masculine self perceptions (Brodsky, 1993) such as confidence, a sense of adventure and risk taking. Extrinsic factors include family circumstances and family orientation, the influence of socio-cultural factors, the political-economic climate surrounding the business environment and dominant features of human resources within the labour market (Ituma \& Simpson, 2007). The aspiration to own and manage a business might stem from a desire to be self-sufficient, to gain personal satisfaction and esteem as well as a desire for more opportunities and flexibility than exists for women in the employed labour market (Carter, 2000; Winn 2004, 2005; Carter and Cannon, 1992). This quest for autonomy and flexibility may be particularly relevant for those women with caring responsibilities (Carter, 2000; Hewlett, 2002) who accordingly seek to combine work and non-work activities.

Other works have explored the specific challenges that women face as entrepreneurs. These include exclusion from formal and informal networks (Carter, 2000), less favourable credit 
terms (Riding and Swift, 1990; Marlow and Patton, 2005) and negative stereotyping as 'less serious' business (Lewis, 2006). As Verheul \& Thurik (2000) found, female entrepreneurs spend less time networking than male counterparts and, despite attempts in the UK to allow equal access to finance and credit (Harding, 2004), gender disadvantage in these areas are seen to persist (Marlow, 2006; Carter and Rosa, 1998; Marlow and Patton, 2005; Roper and Scott, 2009). This may reflect the masculine nature of finance and credit structures which, from Warren-Smith and Jackson (2004) have been designed to favour men, and/or, as Lewis (2006) intimates, lingering concerns that women are less committed and unable to handle the risk and volatilities of a business enterprise.

Recent work has drawn attention to how notions of the successful entrepreneur are often written in masculine terms (Bruni et al, 2004; Lewis, 2006; Ahl, 2006). Such understandings draw on a rhetoric of enterprise (discovery, exploration, commitment, risk) as well as on symbolic meanings around heroism, initiative, leadership and self-reliance and point to their location within the masculine domain. These are embodied in conventional ('male') entrepreneurship models which emphasise size, growth and profit (Fenwick, 2002; Lee-Gosselin and Grise, 1990) while alternative ('female') ways of organizing based for example around stability and work-life balance are devalued and marginalised (Lewis, 2006). As Marlow and Patton (2005) argue, these gendered characterizations can impede the full realization of women's business potential. Thus, as Carter (2000) points out, women are not disadvantaged in the world of self employment because of their lack of mental, physical, educational and other kinds of abilities, but as a result of gendered categorisations. These categorizations have close links to other variables, such as cultural values, family commitment, lack of business capital and credit facilities that can act as limitations to the female entrepreneur. 


\section{FEMALE ENTREPRENEURIAL DEVELOPMENT IN NIGERIA}

Several studies have indicated that the emergence of female entrepreneurs in a society depends to a great extent on the challenges they encounter towards entrepreneurial development. These challenges are often underpinned by the economic, cultural and religious environment (D'Souza et al., 2000; Kitching \& Woldie, 2004). In terms of the former, Nigeria as an extremely diverse country has undergone considerable economic development over the last ten years of democratic rule, with over 200 international companies currently operating within its domains (Geo-Jaja and Mangum, 2000). Despite this, it continues to be characterised by wide-scale poverty and to have high levels of unemployment estimated at 4.9 percent in 2007 (CIA World Factbook, 2009; Library of Congress, Nigeria Profile, 2008). Within the last decade, the Nigerian industrial sector has come to be dominated by small-scale enterprises which constitute $66 \%$ of all industrial establishments (UNIDO, 2001). A large number of these workers are engaged in the informal sector, characterised by low capital, ease of entry and preponderance of family ownership. It is in this sector that the majority of female entrepreneurs are located, where they outnumber their male counterparts (Aderemi et al., 2008).

The desire by women in Nigeria to own their business is partly influenced by the intense struggle for scarce employment opportunities among an over-populated reserve army of men and women (Mordi and Mmieh, 2009). The move into entrepreneurship may also reflect a need to break away from the male hegemony that permeates work settings and restricts female upward mobility. However, these entrepreneurial activities often conflict 
with normative constructions of gender. In this respect, the desire by female entrepreneurs to recreate work environments and to be in control, 'intolerant of limits defined by others' is viewed as a threatening to men (Brodsky, 1993:341). These traits and behaviours come into conflict with gender expectations that women should be humble and modest and, through the priority given to their roles as wives and mothers, that they should take a lesser role in business or income earning activities (Zakaria, 2001). Often women in Nigerian are treated as minors and as subservient, even though the Nigerian constitution gives women equal rights as men. This value system is reinforced by religious philosophies that are based on patriarchal thought systems in which the 'god-given' roles of women are that of mother and wife - caring roles and obligations that often extend outside the immediate family. The asymmetry and ascendancy of males over females in the labour market are clearly seen in patriarchal communities, whereas in Nigeria there is a large power distance and high masculinity (Hofstede, 1980) and where customs place the obligation on the male child to be the economic provider, emotional protector and leader.

As Madichie (2009) has pointed out, Nigerian societal structures have facilitated the transmission of conservative socio-cultural values and have fuelled in part socio-inhibitions through traditions that are embedded in policy, legal environment and institutional support mechanisms. While, as Woldie and Adersua (2004) note, a gradual but significant shift away from these trends and a lessening of gender inequalities are apparent as countries such as Nigeria become more democratic, women still have difficulty challenging the subjugated role society had given them. This is likely to have severe implications for their abilities to successfully manage their enterprises, not just in terms of time constraints as they carry out 
their family obligations, but in terms of exclusions from key networks, lack of self confidence, lack of credibility and institutional arrangements that affect the ability of women to raise capital and other finance. As McElwee and Al-Riyami (2003) argue, in counties where women are allowed limited freedom to associate with men other than their husbands or sons, the size of the networks will be small and the composition will be largely female - factors that may starve women of useful information sharing, appropriate data on customers/suppliers or mentorship (Woldie \& Adersua 2004). This situation, as we can infer from points made above, may also be relevant in Nigeria. In terms of finance, banks in Nigeria have been found to operate a binary loan and credit grant process which raise barriers for women in terms of granting loans, partly because they are less likely to have the necessary collateral or important family ties (Histrish \& Ozturk, 1999; McElwee \& Al-Riyami, 2003; O'Neil, 2001) and partly due to gender stereotypes that favour men (Kibanja \& Munene, 2009).

\section{METHOD}

Taken together, the literature indicates that female entrepreneurs face a variety of challenges that may well impede them in their desire to run and manage their own businesses. These challenges can be seen to be based on 1) personal factors 2) gender and family based factors and 3) market based challenges. These form the basis of the propositions set out below.

Proposition 1: female entrepreneurs in Nigeria experience challenges relating to personal/individual factors (e.g. lack of training, skills, lack of confidence) 
Proposition 2 female entrepreneurs in Nigeria experience challenges relating to gender and familial factors (e.g. gender discrimination, sexual harassment; lack of recognition from the business community; negative attitudes and lack of support from spouse).

Proposition 3: female entrepreneurs in Nigeria experience challenges that relate to market based factors (e.g. lack of access to finance, market competition; economic conditions).

Primary data used in the study came from a larger survey based on 274 female entrepreneurs currently engaged in their businesses in three states-Lagos (Nigeria's largest city), Ogun, and Oyo within the south west of Nigeria. Relevant agents in our study are women entrepreneurs who chose the route to entrepreneurship in one of following three ways: by starting a business venture from scratch, by inheriting the family business or by purchasing a going concern. $\mathrm{A}$ small scale entrepreneur was defined as one having up to 10 employees and assets worth not less than one million Naira. A population list representing 2150 entrepreneurs engaged in agriculture, manufacturing, trade, and services was constructed. Of these a sample size of 570 was formed using a mix of random and stratified sampling methods. Out of the 570 questionnaires distributed to the respondents, 422 or $74 \%$ were received. Cross-checking and the process of matching the sample with defined characteristics above produced 274 usable questionnaires.

The questionnaire included items relating to background, perceptions, potential and actual business environment, motivation and challenges faced in the business. The analysis in this paper is based on relevant background characteristics (e.g. demographic characteristics, family background, perceptions regarding entrepreneurial attitudes and characteristics such as risk taking, creativity, desire for independence and challenge) and on one section that 
referred to the challenges female entrepreneurs may face. Here, respondents were required to rank eighteen possible challenges, informed by the literature, in the order in which they were perceived to have affected the business enterprise. These included personal factors (e.g. lack of training, lack of advice/support, lack of energy and time); gender and familial factors (e.g. combining family responsibilities with work; gender discrimination, sexual harassment, husband's attitude to the enterprise); market based factors (e.g. lack of access to finance; gaining acceptance in the market/lack of access to networking; lack of access to IT; managing competition, unfavourable economic conditions).

Descriptive statistics were drawn from frequency tables regarding background characteristics and self perceptions as well as initial rank ordering of the 18 challenges posed. This allowed a broad picture to be drawn of profile and of the key challenges faced. Zero order correlations were conducted on background statistics. These included age, age when the business was started, education, marital status, religion, number of children/dependents, years worked for another organization before business start-up, whether parents were self employed, whether the business was set up immediately after stopping work, training related to the business, participation in the family business, location, mode of start-up and hours worked. Each was binary coded e.g. age was coded into two groups containing female entrepreneurs either under or over the age of 33; marital status was coded into one group containing single women and the second containing married, divorced and widowed. Rank order correlations were conducted on the list of 18 challenges women were asked to rank in order of importance, with a specific focus on those challenges that had emerged from frequency tables as particularly significant. 


\section{RESULTS}

\section{Profile and Personal Characteristics}

The majority of women (75\%) were under 35 and nearly a half $(47.1 \%)$ had started their business at a young age (between 19 and 24 years). Two thirds (64\%) were married and with children and the majority (77.9) had a post-school qualification. Two thirds (61.3\%) had started their business 'from scratch' rather than buying into a business at a later stage or joining a going concern. The majority were sole traders (83.2\%) as opposed to being in partnership or in a company, and they were likely to be in trade $(36.9 \%)$ or in services $(35.7 \%)$. Only one third $(32.7 \%)$ described their business as a 'family business', though over a half (58\%) had self employed parents and had participated in the family business when younger. The majority (61.6\%) employed between 10 and 13 people.

In terms of ownership of entrepreneurial traits, positive self perceptions emerged. For example, in each of the following cases, two thirds either agreed or strongly agreed that they enjoyed taking risks; that they enjoyed pursuing difficult goals; that they wanted to be independent and to seek self esteem and confidence; and that they had control over their business resources through their own efforts. Similarly, three quarters felt they had energy and strength required to run their business; that they were creative and innovative; enjoyed challenge and that they valued a sense of self achievement. One third described themselves as the family breadwinner.

From Table 1, zero order correlations suggest the following: that the characteristic mode of start-up ('from scratch') was significantly the case for younger women under the age of 33 (0.13), for those women whose parents were self employed (0.12) and for those who had some previous experience relating to the business (0.10). These women were also likely to be located in a large city (0.20). Having self employed parents further emerged as a possible 
facilitating factor to self employment in that women were more likely to have acquired experience/training working outside $(0.12)$ and to have started their business immediately after a period of work (0.17). Married women and those with dependents were, not surprisingly, less likely to put in long working hours $(-0.19 ;-0.16$ respectively). Neither education background, marital status nor religion appears to strongly correlate with other variables.

\section{Insert Table 1 here}

\section{Challenges Faced}

Respondents were asked to rank (1-18) the importance of a series of potential challenges faced in their entrepreneurial career.

Insert Table 2 here

From descriptive statistics of this ordering, the item 'family responsibilities' emerged as the most important factor $(49.3 \%$ of the sample ranked this in the top 3 challenges faced and $25.6 \%$ as the top challenge). Cross tabulations indicate that this figure rises to $50 \%$ for younger women (under 33 years). Interestingly, even single women have rated this highly: $35 \%$ ranked this as one of the top 3 challenges faced. This was followed by lack of access to finance (ranked in the top 3 by $44.1 \%$ ), sexual harassment (ranked in the top 3 by 33.5\%) and lack of support and assistance (ranked in the top 3 by $29.1 \%$ ). Other key challenges encountered include lack of advice on business issues (ranked in the top 3 by 25.1\%), coping with competition (ranked in the top 3 by 23.5\%), high rent/tenement rates (ranked in the top 3 by $21.8 \%$ ) and lack of time and energy (ranked in the top 3 by $20.6 \%$ ). Interestingly, 
gender discrimination was only chosen as in the top 3 challenges by $17.7 \%$ of the sample. Moreover, while $15.9 \%$ identified 'my husband does not like what I am doing' as in the top 3 challenges faced, over one fifth (20.8\%) strongly rejected this notion, positioning the item last in the ordering (the highest figure in this bottom group).

\author{
Insert table 3 here
}

In terms of rank correlations, some key findings emerge. First, the challenge posed by the burden of family responsibilities, ranked first by the largest percentage of the sample, correlates significantly with lack of advice on business issues (0.13) and lack of opportunity for training and upgrading skills (0.14). Secondly, lack of access to finance, also ranked highly, is associated with difficulties finding acceptance in the market and respect from their customers (0.22), lack of IT facilities (0.13) and finding right contacts for networking $(0.20)$. These are all largely market based variables. Thirdly, lack of advice on business issues, chosen as one of the top 3 challenges by a quarter of the sample, is associated in particular with problems gaining acceptance in the market and gaining respect from customers (0.41), lack of opportunity to get training or to upgrade skills (0.44), lack of access to IT (0.19), finding the right contacts and networks (0.19) and problems of sexual harassment (0.19).

\title{
DISCUSSION AND CONCLUSION
}

This paper set out to explore the challenges faced by female entrepreneurs in the context of Nigeria. In so doing, it acknowledges the importance of the often unrecognised contribution that women make to the Nigerian economy in their entrepreneurial activities (Aderemi et al, 
2008; Kitching and Woldie, 2004) and responds to a call (de Bruin et al, 2007; Blackburn and Kovalainen, 2009; Gartner, 1995; Carter, 2000; Kitching and Woldie, 2004) for more work focussing on the experiences of female entrepreneurs in a non-Western context. The paper is organized around three key propositions about challenges faced that emerged from the literature. These concern 1) personal factors (e.g. lack of education/training; lack of confidence) 2) gender and family based factors (e.g. family responsibilities, gender discrimination) and 3) market based factors (e.g. lack of access to finance; government regulation, economic conditions).

\section{Personal Factors}

There was little evidence from the data to support the proposition that female entrepreneurs in Nigeria face challenges that relate to personal or 'individually based' factors. Most are educated to post-school standard and exhibit self perceptions that are associated with strong entrepreneurial predispositions. Thus female entrepreneurs enjoy risk taking and the challenge of taking on difficult tasks, value independence and autonomy and see themselves as creative and innovative - key ingredients of so-called 'entrepreneurial self efficacy' (Mueller and Dato-On, 2008) and which form the basis of intrinsic factors likely in a general context to influence women to seek out an entrepreneurial career (Akrivos et al, 2007; Carter, 2000). Most started their businesses very young and a large minority are family breadwinners. The level of confidence and self belief exhibited by these self perceptions may be reflected in the mode of entry: the majority had started their businesses from scratch - and were running them on their own - an undertaking that is likely to be more risky than buying into a going concern and which is also likely to demand more entrepreneurial ability and resourcefulness. However, despite this, 
there is evidence that women encounter a lack of support in their ventures and that they would welcome the opportunity to further upgrade their skills.

\section{Gender based and Family Factors}

Results support the notion that some gender and family based factors are key to understanding the challenges faced by women in this context. In this respect, the pressure of family responsibilities emerged as the most important factor. What is interesting here, however, is the importance placed on this factor irrespective of marital status in that even single women identify this as one of the top three challenges faced. However, while a sizeable minority feel that their husbands are a source of constraint in that they are seen to be unsupportive to their entrepreneurial work, an equal number strongly reject this notion - a polarization unique to this item. This may reflect both a recognition of patriarchal values within the family and an experience of support and/or familial loyalty. Given that Nigeria is a strongly patriarchal society (Kuada, 2009; Broysen, 1999), it may be anticipated that gender discrimination would be experienced as a key challenge. However, from the data only a minority identified this as an issue. Sexual harassment was instead, and somewhat paradoxically, a major problem identified. This form of behaviour by men has emerged from other studies in this and similar contexts as a common experience for women (Lodebo, 2003), possibly reflecting patriarchal attitudes to those women who venture into the public sphere (Brodsky, 1993; Zakaria, 2001; Woldie and Adersua, 2004). One possibility for this paradox is that the choice of sexual harassment as an overt form of discrimination 'overrode' the more 'oblique' description of gender discrimination and that the latter item was accordingly less likely to be selected. Alternatively, the language of discrimination may not 
be so 'mainstream' in this context (compared to the West which is steeped in equal opportunity ideologies) and so had less purchase in women's experiences.

\section{Market Based Factors}

Results support the proposition that market based factors form the basis of key challenges facing female entrepreneurs in Nigeria. In this respect, lack of access to finance was the most significant - an issue that can impact on growth prospects as well as on the day to day running of the enterprise. Previous research has attested to a level of discrimination towards women in this regard both in a Western context (Marlow, 2006; Roper and Scott, 2009) and in Nigeria where banks are often reluctant to lend to women and where they frequently operate a binary system that favours men (Histrish and Ozturk, 1999; McElwee and Al-Riyami, 2003; O'Neil, 2001). This issue was closely correlated with other market related factors including, in particular, difficulties finding acceptance in the market and respect from customers (experienced as one of top three challenges by one fifth of the sample) and finding right contacts for networking. Lack of advice on business issues emerges as a further issue. Key environmental and infra-structural issues include high rents and inconsistent power supplies.

\section{The Significance of Cultural Values}

Overall, these results have provided insight into the challenges faced by female entrepreneurs in the context of Nigeria. These suggest, as Carter (2000) found in a Western context, that women are not disadvantaged because of personal factors such as lack of mental, educational or other kinds of abilities, but more as a result of gendered categorisations and cultural values. In fact, Nigerian women emerge as particularly confident and resourceful in their entrepreneurial career. This aligns with Madichie's (2009) 
work on Nigerian women managers who, he argues, may be overcoming some of the barriers that have traditionally constrained them.

These gendered and cultural factors have close links to key variables that emerged from the study such as family commitments and lack of access to finance - and which have strong links to other factors. In terms of the family, even single women are constrained by these commitments, reflective of traditional expectations regarding women's role in fulfilling familial obligations (Ituma and Simpson, 2007; 2009; Zakaria, 2001) - and as we have seen, discriminatory practices still permeate in banking in terms of finance decisions. These and other norms and practices underpin patriarchal values that are particularly strong in Africa (Kuada, 2009; Broysen, 1999) and which may additionally influence the level of acceptance and respect women are afforded by market players and within key networks. In its extreme form, patriarchal attitudes can translate into sexual harassment as a response to women who 'step out of line' (Collinson and Collinson, 1996) and enter the (masculine) public space of work and enterprise. Thus, while the nature of some of these challenges (e.g. family commitments, lack of access to finance, detrimental attitudes) has been found in other contexts, their depth and intensity may well differ and depend on the specifics and degree of hegemony of cultural (e.g. patriarchal) values in situ. Women in the West may face problems raising finance (Riding and Swift, 1990; Marlow and Patton, 2005) but not to the degree that an explicitly dual allocation system exists; female entrepreneurs in the UK may have difficulties combining career with demands of family (Carter, 2000; Hewlett, 2002; Orhan and Scott, 2001), but single women without children are likely to be exempt; female business owners in the UK may struggle to be seen as 'serious enterprise' (Lewis, 2006) but 
they are generally accepted in the market and it is unlikely that a high proportion will claim they are sexually harassed. In short, while there may be commonalities across national contexts in terms of 'type' of challenge encountered, there are differences that, influenced by cultural and patriarchal values, relate to depth and degree and which 'play out' differentially in each situation.

\section{Policy Implications and Future Research}

These results are important in understanding the specific problems Nigerian female business owners face. As we discussed earlier, self-employment in this, as in other similar contexts, can be sought as a means to alleviate poverty and gender based occupational segregation (Alarape, 2009) and can make a significant contribution to the formal and informal economy (Aderemi et al, 2008). The fact that many women feel unsupported in their ventures opens the door to policy prescriptions in the form of access to training and finance, the provision of IT facilities and networking support - all of which have been identified in this study as problematic areas. Perhaps more importantly, and given the apparent facilitating effect of a family background in enterprise, is the need to give full recognition to the contribution that women make, not just to their own families and wider communities, but as exemplars to the next generation of female entrepreneurs.

This study has gone some way to 'close the gap' in terms of our understanding of some of the challenges female entrepreneurs face in an African context. In this respect we have obtained, through our data, a 'snapshot' of what some of these challenges look like. A next step might be to conduct a more in -depth qualitative analysis of women's experiences and the 'stories' of their work to explore how these identified factors are further experienced in their specific contexts. In other words, despite limitations in terms of a more in-depth 
understanding - an issue that applies to much quantitative research - this study has surfaced some key issues that will help frame further work. 


\section{REFERENCES}

Aderemi, H. O., Ilori, M. O., Siyanbola, W. O., Adegbite, S. A., Abereijo I. O. (2008). 'An assessment of the choice and performance of women entrepreneurs in technological and non-technological enterprises in south-western Nigeria'. African Journal of Business Management. Vol 2 No 10. pp 165-176.

Ahl, H. (2006) 'Why Research on Women Entrepreneurs needs New Directions'. Entrepreneurship Theory and Practice, Vol 30 No 5 pp. 595-621

Akrivos, C., Ladkin, A., Rekitis, P. (2007). 'Hotel managers career strategies for success'. International Journal of Contemporary Hospitality Management, Vol 19 No 2. pp 107-19.

BBC online (2001). Nigeria "Fuelled" by Black Economy', Monday 3 December. http://news.bbc.co.uk/1/hi/business/1689165.stm.

Bird, B. and Brush, C. (2002). 'A gendered perspective on organizational creation'. Entrepreneurship Theory and Practice, Vol 26 No 3. pp 41-65.

Blackburn, R., \& Kovalainen, A. (2009). 'Researching small firms and entrepreneurship: Past present and future. International Journal Management Reviews, Vol 11 No 2. pp 127-148.

Boohene, R. (2009). 'The relationship among gender, strategic capabilities and performance of small retail firms in Ghana. Journal of African Business, Vol 10 No 1. pp 121-135.

Brodsky, M.A. (1993). 'Successful female corporate managers and entrepreneurs: similarities and differences'. Group and Organization Management, Vol 18, No 3. pp 366378

Bruni, A., Gherardi, S., and Poggio, B. (2004). 'Doing gender, doing entrepreneurship: An ethnographic account of intertwined practices. Gender Work and Organization, Vol 11. No 4. pp 406-429

Brush, C. (1997). Women owned businesses: Obstacles and opportunities, Journal of Developmental Entrepreneurship. Vol 2. No 1. pp 1-25.

Carter, S., \& Rosa, P. (1998). 'The financing of male and female owned business'. Entrepreneurship and regional development. Vol. 10. No. 3: 225-241.

Carter, S. (2000). 'Gender and Enterprise'. In Carter, S., Jones-Evans, D. (Eds.), Enterprise and Small Business: Principles, Practice and Policy, Financial London: Times Prentice-Hall.

Carter, S. and Marlow, S. (2003). 'Professional attainment as a challenge to gender disadvantage in enterprise'. Paper presented at $48^{\text {th }}$ International Small Business Conference, June, Belfast.

Carter, S. and Cannon, T. (1991). Women as Entrepreneurs: A Study of Female Business Owners, Their Motivations, Experience and Strategies for Success. London: Academic Press.

Casson, M. et al. (2006). The Oxford Handbook of Entrepreneurship. Oxford: Oxford University Press. 
CIA World Fact book entry on Nigeria (2009).

http://www.cia.gov/cia/publications/factbook/geos/ni.html.

Collinson, M. and Collinson, D. (1996) 'It's only Dick: The sexual harassment of women managers in insurance sales work'. Work Employment and Society, Vol10 No 1. pp 29-56

D'Souza, C., Lim, S., and Hewarathna, R. (2000). Gender impact on women entrepreneurs: A cultural analysis, Discussion papers, LA Trobe University.

De Bruin, A., Brush, C., and Welter, F. (2007). 'Advancing a framework for coherent research on women's entrepreneurship'. Entrepreneurship, Theory and Practice, Vol 31. No 3. pp 323339.

Gartner, W. B. (1990). 'What are we talking about when we talk about entrepreneurship?' Journal of Business Venturing, Vol 5: 15-28.

Gartner, W. B. (1995). 'Aspect of organisational emergence'. In Bull, H. Thomas and G. Willard (Eds.) Entrepreneurship: Perspectives on Theory Building. Oxford: Pergamon.

Gartner, W. B., Shaver, K. G., Carter, N. M. and Reynolds, P. D. (2004). The Handbook of Entrepreneurial Dynamics. Sage: Thousand Oaks.

Geo-Jaja, M. and Mangum, G.L. (2000). 'The foreign corrupt practices act's consequences for US trade: the Nigerian example' Journal of Business Ethics. Vol 24. No 3. pp 245-55.

Goffee, R. and Scase, R. (1985). Women in Charge. HarperCollins.

Harding, R. (2004). Global Entrepreneurship Monitor UK 2004. London: GEM.

Hewlett, S.A. (2002). Creating a Life: Professional women and the quest for Children. New York: Talk Miramax Books.

Hisrich, R.D. and Ozturk, S.A. (1999). 'Women entrepreneurs in a developing economy'. The Journal of Management Development Vol 18. pp 114-124.

Hofstede, G. (1980). Culture's Consequences: International Differences in Work-Related Values. London: Sage.

Ituma, A. N. and Simpson, R. (2007). 'Moving beyond Schein's typology: career anchors of IT workers in Nigeria. Personnel Review Journal. Vol 36. No 6. pp 978-995.

Ituma, A. N. and Simpson, R. (2009) The 'Boundaryless' Career and Career Boundaries: Applying an Institutionalist Perspective to ICT workers in the Context of Nigeria, Human Relations, Vol 62. No 5. pp727-762

Kinbanja, G. M. and Munene, J. (2009). 'Finance and performance of small medium size enterprises (SMEs). Journal of African Business. Vol 10. No 1. pp 105-121.

Kitching, B. M. and Woldie, A. (2004). 'Female entrepreneurs in transitional economies: a comparative study of business women in Nigeria and China'. In Proceedings Hawaii International Conference on Business, Honolulu: Hawaii. 
Kuada, J. (2009). 'Gender, social networks and entrepreneurship in Ghana'. Journal of African Business. Vol 10. No 1. pp 85-104.

Lewis, P. (2006) 'The quest for invisibility: female entrepreneurs and the masculine norm of entrepreneurship', Gender Work and Organization, Vol 13. No 5. pp 623-646

Library of Congress - Federal Research Division Country Profile: Nigeria, July 2008. http://memory.loc.gov/frd/cs/profiles/Nigeria.pdf.

Lodebo, O. (2003) 'Sexual harassment in academia in Nigeria: how real?' African Sociological Review, Vol 7 No. 1. pp 00-00

Madichie, N. O. (2009). 'Breaking the glass ceiling in Nigerian: a review of women's entrepreneurship'. Journal of African Business. Vol 10. No. 1.pp 51-65.

Marlow, S. (2006). 'A safety net or ties that bind?: Women, welfare and self-employment'. International Journal of Sociology and Social Policy. Vol 26. No 9-10. pp 397-410.

Marlow, S. and Patton, D. (2005). 'All credit to men, entrepreneurship, finance and gender', Entrepreneurship, Theory and Practice. Vol 29.No 6. pp 699-716.

McElwee, G. and Al-Riyami. R. (2003). 'Women entrepreneurs in Oman: some barriers to success'. Career Development International, No 8 Vol 7. pp 339-346.

Mordi, C. and Mmieh, F (2009). Divided Labour and divided in-firm markets in the Nigerian Petroleum sector. In Proceedings of the $10^{\text {th }}$ International Academy of African Business and Development. http://www.iaabd.org/2009 iaabd_proceedings/track13j.pdf

Morris, M. H. and Hopper, V. A (1996). Contemporary issues in entrepreneurship: research perspectives from within South Africa. Southern African Journal of Entrepreneurship and Small Business. Vol 8 no 2. pp 14-15.

Mueller, S. and Conway Dato-On, M. (2008) 'Entrepreneurial self efficacy'. Journal of Developmental Entrepreneurship, Vol 13. No 1: 45-58

National Foundation of Women Business Owners (1998). Women Entrepreneurs Are a Growing Trend, National Foundation of Women Business Owners. Washington, DC.

O'Neil, R. C. and Viljoen, L. (2001). 'Support for female entrepreneurs in South Africa: Improvement or decline?' Journal of Family Ecology and Consumer Sciences. Vol 29. pp 3744.

Orhan, M. and Scoot, D. (2001).'Why Women enter into Entrepreneurship: an Explanatory Model'. Women in Management Review. Vol 16. No 5. pp 232-243.

Roper S. and Scott J M, (2009). 'Perceived financial barriers and the start-up decision: an econometric analysis of gender differences using GEM data'. International Small Business Journal Vol 27. No 2. pp149-171.

Rugman, A. and Collinson, S. (2009). International Business, Prentice Hall. 
Sexton, D. and Bowman-Upton, N. (1990). 'Female and male entrepreneurs: psychological characteristics and their role in gender-related discrimination'. Journal of Business Venturing. Vol 5. pp 29-36.

Simpson, R. (2009). Men in Caring Occupations: Doing Gender Differently. Palgrave.

Spring, A. (2009). Gender-related Themes in African Entrepreneurship. Journal of African Business. Vol 10.No 1. pp 1-10.

The Nigerian Guardian Newspaper (2009). Passports issuance and the rights of married women. http://www.ngrguardiannews.com/editorial opinion/article01/190609.

UNIDO (2001). Women entrepreneurship in selected African countries. Working paper No.7, Vienna: UNIDO.

Verheul, I. and Thurik, R (2000). 'Start-up capital: differences between male and female entrepreneurs: Does Gender Matter?' Erasmus Research Institute of Management (ERIM) Report ERS-2000-07-STR. Rotterdam: Netherlands.

Warren-Smith, I. and Jackson, C. (2004). 'Women creating wealth through rural enterprise'. International Journal of Entrepreneurial Behaviour \& Research. Vol 10. No 6. pp 369-383.

Winn, J. (2004). 'Entrepreneurship: not an easy pathway to top management for women'. Women in Management Review. Vol 19. No 3. pp 145-153.

Winn, J. (2005). 'Women entrepreneurs: can we remove the barriers?' International. Entrepreneurship and Management Journal, Vol 1: 381-397.

Woldie, A. and Adersua, A. (2004). 'Female entrepreneurs in a transitional economy: Business women in Nigeria'. International Journal of Social Economics. Vol 31. No 1. pp 7893.

Zakaria. Y. (2001). 'Entrepreneurs at home: secluded Muslim women and hidden economic activities in Northern Nigeria'. Nordic Journal of African Studies. Vol 10. No 1. pp 107-123. 
Table-1 : Zero-order Correlation Table of Background Factors

\begin{tabular}{|c|c|c|c|c|c|c|c|c|c|c|c|c|c|c|c|c|c|c|}
\hline \begin{tabular}{l|l} 
No. & Variables \\
\end{tabular} & 1 & 2 & 3 & 4 & 5 & 6 & 7 & 8 & 9 & 10 & 11 & 12 & 13 & 14 & 15 & 16 & 17 & 18 \\
\hline 1.Age & 1 & & & & & & & & & & & & & & & & & \\
\hline $\begin{array}{l}\text { 2.Age started the } \\
\text { business }\end{array}$ & $-.26 * *$ & 1 & & & & & & & & & & & & & & & & \\
\hline 3.Qualification & $-.16^{*}$ & -.07 & 1 & & & & & & & & & & & & & & & \\
\hline 4.Education Background & $.14^{*}$ & .05 & $-.18 * *$ & 1 & & & & & & & & & & & & & & \\
\hline 5.Marital status & $.37^{* *}$ & $-.33 * *$ & $-.16 * *$ & .01 & 1 & & & & & & & & & & & & & \\
\hline 6.Religion & -.03 & .05 & $.26 * *$ & -.03 & -.08 & 1 & & & & & & & & & & & & \\
\hline 7.Child status (number) & $.36 * *$ & $-.22 * *$ & -.04 & -.02 & $.14^{*}$ & .02 & 1 & & & & & & & & & & & \\
\hline $\begin{array}{l}\text { 8.Dependent status } \\
\text { (number) }\end{array}$ & .12 & $-.17 * *$ & $.14^{*}$ & $-.13 *$ & $.25^{* *}$ & -.03 & $.34^{* *}$ & 1 & & & & & & & & & & \\
\hline 9.Years Worked & $.23 * *$ & $-.21 * *$ & -.02 & -.03 & $.25^{* *}$ & -.03 & $.16^{*}$ & $.18^{*}$ & 1 & & & & & & & & & \\
\hline $\begin{array}{l}\text { 10.Self employed } \\
\text { parents }\end{array}$ & $.12 *$ & -.11 & $-.12 *$ & .11 & .05 & -.02 & .00 & -.09 & -.07 & 1 & & & & & & & & \\
\hline $\begin{array}{l}\text { 11.Experience (years } \\
\text { worked) }\end{array}$ & $.12^{*}$ & .04 & -.03 & .02 & .09 & .00 & .08 & -.02 & -.06 & $.13^{*}$ & 1 & & & & & & & \\
\hline $\begin{array}{l}\text { 12. When started } \\
\text { business }\end{array}$ & .00 & .01 & -.05 & .09 & .02 & -.02 & .02 & -.04 & .02 & $.17^{* *}$ & $.31 * *$ & 1 & & & & & & \\
\hline $\begin{array}{l}\text { 13. Relationship to } \\
\text { previous work }\end{array}$ & .10 & .01 & -.01 & $.22^{* *}$ & -.02 & .06 & .10 & -.01 & .01 & $.12 *$ & $.28 * *$ & $.30 * *$ & 1 & & & & & \\
\hline $\begin{array}{l}\text { 14. Training in the } \\
\text { business }\end{array}$ & -.10 & -.09 & .09 & .03 & $-.12 *$ & .03 & -.02 & .07 & .11 & .02 & -.03 & -.00 & $.17^{* *}$ & 1 & & & & \\
\hline $\begin{array}{l}\text { 15.Participate in family } \\
\text { business }\end{array}$ & -.01 & -.01 & .01 & -.04 & -.03 & .07 & -.04 & .11 & .02 & .06 & $-.11 *$ & -.07 & -.07 & .03 & 1 & & & \\
\hline 16.Location & $.20 * *$ & $.15^{* *}$ & -.11 & $.16^{* *}$ & $.15^{* *}$ & -.03 & $.14 *$ & -.05 & -.10 & .10 & $.18^{* *}$ & .07 & .09 & $-.13^{*}$ & -.03 & 1 & & \\
\hline 17. How business started & $.13^{*}$ & .06 & -.08 & .04 & -.02 & -.01 & -.00 & .02 & .11 & $.12 *$ & .10 & .08 & $.11^{*}$ & .04 & .01 & $.16^{* *}$ & 1 & \\
\hline 18. Hours worked & $-.12^{*}$ & $.12^{*}$ & .02 & .00 & $-.19 * *$ & .00 & .07 & $-.16^{*}$ & -.08 & -.03 & 0 & -.01 & .02 & .08 & .05 & $.17^{* *}$ & .03 & 1 \\
\hline
\end{tabular}

Note: $*^{*}=.10, * *=.05, * * *=.01$ significance level 
Table 2: Challenges Faced by Female Entrepreneurs

\begin{tabular}{|l|l|l|l|}
\hline Item & $\begin{array}{l}\text { Ranked first } \\
\text { by (\%) }\end{array}$ & $\begin{array}{l}\text { Ranked in Top } \\
\mathbf{3} \text { by (\%) }\end{array}$ & $\begin{array}{l}\text { Ranked last } \\
\text { by (\%) }\end{array}$ \\
\hline 1. Family responsibilities & 25.6 & 49.3 & 2.6 \\
\hline 2. Lack of access to Finance & 19.6 & 44.1 & 1.5 \\
\hline 3. No-one advising me & 5.2 & 25.1 & 2.9 \\
\hline 4. Gaining acceptance in the market & 7.1 & 20.8 & 2.6 \\
\hline 5.No opportunity to upgrade skills & 6.0 & 20.1 & 3.3 \\
\hline 6.Lack of support and assistance & 12.7 & 29.1 & 1.8 \\
\hline 7.Lack of access to IT & 6.0 & 18.5 & 2.9 \\
\hline 8.Finding right contacts/networking & 4.9 & 15.7 & 2.9 \\
\hline 9.Sexual Harassment & 17.5 & 33.5 & 2.6 \\
\hline 10.Coping with competition & 5.7 & 23.5 & 2.9 \\
\hline 11.High rent/tenement rates & 7.7 & 23.5 & 3.6 \\
\hline 12.Customer complaints & 6.9 & 20.7 & 3.6 \\
\hline 13.Inconsistency in power supplies & 6.6 & 23.0 & 2.9 \\
\hline 14.Too much government regulation & 6.0 & 18.5 & 2.9 \\
\hline 15.Gender discrimination & 5.6 & 17.7 & 2.9 \\
\hline 16.Lack of time/energy & 6.7 & 15.9 & 2.9 \\
\hline $\begin{array}{l}\text { 17.My husband does not like the business I } \\
\text { am in }\end{array}$ & 4.9 & & \\
\hline 18 Unfavourable economic conditions & 3.1 & & \\
\hline
\end{tabular}


Table 3 : Rank Correlation of Challenges faced by the Entrepreneurs

\begin{tabular}{|c|c|c|c|c|c|c|c|c|c|c|c|c|c|c|c|c|}
\hline 1 & 2 & 3 & 4 & 5 & 6 & 7 & 8 & 9 & 10 & 11 & 12 & 13 & 14 & 15 & 16 & 17 \\
\hline 1 & & & & & & & & & & & & & & & & \\
\hline $.13^{*}$ & $.21^{* *}$ & 1 & & & & & & & & & & & & & & \\
\hline .05 & $.22 * *$ & $.41^{* *}$ & 1 & & & & & & & & & & & & & \\
\hline $.14^{*}$ & .09 & $.44^{* *}$ & $.32^{* *}$ & 1 & & & & & & & & & & & & \\
\hline-.05 & $.20 * *$ & $.13^{*}$ & $.29 * *$ & $.21^{* *}$ & 1 & & & & & & & & & & & \\
\hline-.01 & $.19 * *$ & $.19 * *$ & $.22 * *$ & $.28^{* *}$ & $.30 * *$ & 1 & & & & & & & & & & \\
\hline .00 & $.20 * *$ & $.19^{* *}$ & $.18^{* *}$ & $.19^{* *}$ & $.26^{* *}$ & $.31^{* *}$ & 1 & & & & & & & & & \\
\hline .05 & -.02 & $.19 * *$ & $.15^{*}$ & $.35^{* *}$ & $.14^{*}$ & $.21 * *$ & $.19 * *$ & 1 & & & & & & & & \\
\hline .02 & .07 & $.13^{*}$ & .10 & .09 & .09 & $.17^{* *}$ & $.18^{* *}$ & $.21^{* *}$ & $.18^{* *}$ & 1 & & & & & & \\
\hline .08 & $.16^{*}$ & $.16^{*}$ & $.20 * *$ & $.31 * *$ & .09 & $.24 * *$ & $.25 * *$ & $.27 * *$ & $.31 * *$ & $.13 *$ & 1 & & & & & \\
\hline .01 & .04 & .01 & -.02 & .02 & .07 & .12 & $.26^{* *}$ & .11 & $.32 * *$ & $.34 * *$ & $.19 * *$ & 1 & & & & \\
\hline .04 & .03 & .03 & $.18^{* *}$ & .12 & .11 & .10 & $.17^{* *}$ & $.24 * *$ & $.231 * *$ & $.27^{* *}$ & $.37 * *$ & $.17^{* *}$ & 1 & & & \\
\hline-.05 & .11 & .05 & $.21^{* *}$ & .12 & $.13^{*}$ & $.20 * *$ & $.23 * *$ & $.29 * *$ & $.17^{* *}$ & $.15^{*}$ & $.31^{* *}$ & $.27^{* *}$ & $.26 * *$ & 1 & & \\
\hline .00 & .04 & -.01 & 00 & .06 & .05 & .01 & $.19 * *$ & .08 & $.19 * *$ & $.16^{*}$ & $.18^{* *}$ & $.27^{* *}$ & $.29 * *$ & $.24 * *$ & 1 & \\
\hline .05 & -.04 & .09 & .12 & $.23^{* *}$ & $.19 * *$ & .10 & $.19 * *$ & $.27^{* *}$ & $.19^{* *}$ & .05 & $.29 * *$ & .08 & $.22^{* *}$ & $.38^{* *}$ & $.19^{* *}$ & 1 \\
\hline-.06 & $-.17^{*}$ & -.02 & .04 & -.03 & -.11 & -.13 & .05 & .11 & .04 & .09 & .04 & $.13^{*}$ & $.21^{*}$ & $.18^{* *}$ & $.21^{* *}$ & $.26 * *$ \\
\hline
\end{tabular}

Note: See Table 2 for item descriptions. ${ }^{*}=.10,{ }^{*}=.05, * * *=.01$ significance level. 
